Proceedings

\title{
Genetic Variability of Graptophyllum Pictum (L.) Griff Accessions from Western Indonesia by Sequence Related Amplified Polymorphism
}

\author{
Dimas Andrianto 1,*, Puspa Julistia Puspita 1, Ukhradiya Magharaniq Safira 1, Danty Oktiana Prastiwi 1, \\ Suci Hermita ${ }^{1}$, Dyah Subositi ${ }^{2}$ and Anshary Maruzy ${ }^{2}$ \\ * Correspondence: dimasandrianto@apps.ipb.ac.id; Tel.: +62-251-8423-267
}

Citation: Andrianto, D.; Puspita, P.J.; Safira, U.M.; Prastiwi, D.O.;

Hermita, S.; Subositi, D.; Maruzy, A. Genetic Variability of

Graptophyllum Pictum (L.) Griff Accessions from Western Indonesia by Sequence Related Amplified Polymorphism. Proceedings 2021, 68, x. https://doi.org/10.3390/xxxxx

Academic Editor:

Published: date

Publisher's Note: MDPI stays neutral with regard to jurisdictional claims in published maps and institutional affiliations.

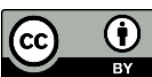

Copyright: (c) 2021 by the authors. Submitted for possible open access publication under the terms and conditions of the Creative Commons Attribution (CC BY) license (http://creativecommons.org/licenses/by/4.0/).

\begin{abstract}
Graptophyllum pictum (L.) Griff is one of the medicinal plants in Indonesia that has been proved to have antioxidant, antidiabetic, and analgesic properties. However, there is no report about the relationship of its genetic diversity with accession and ethnic aspects. Thus, we carried out polymorphism studies and clusterization of 34 samples G. pictum that were collected from 10 ethnics in Western Indonesia. The research purpose was to determine the polymorphism and kinship relations between ethnic groups and accessions of G. pictum in Western Indonesia. DNA was isolated using the GeneJET Plant Genomic DNA purification mini kit. Sequence Related Amplified Polymorphism (SRAP) was used as a molecular marker in PCR amplification. We analyzed the data using NTSYS and PopGene 1.3 softwares. We found 8 combinations of selected primers with polymorphic percentage average of $72.23 \%$ and 45 loci. The ethnicity that has the highest polymorphic percentage is Kutai (East Kalimantan) of $55.56 \%$. The diversity between population and accession is moderate with Dissimilarity Index (DI) not more than 0.69. Ribun ethnic in West Kalimantan is the oldest ancestry ethnic that has locus marker at 24 th and 41 st position. In conclusion, we found that G. pictum in Western Indonesia is divided into 4 clusters.
\end{abstract}

Keywords: accession; Graptophyllum pictum; polymorphism

\section{Introduction}

Indonesia has 188 million hectares land area that are spread on more than 10,000 islands with more than a half of it was covered by primary natural forest [1]. However, many of the species are becoming endangered species because of the decreasing vegetation area in Indonesia rapidly. Another factor that threat biodiversity is anthropogenic and upcoming mining activities, such as logging and land conversion [2,3]. North Sulawesi Province lost up to 12,668.2 hectares forest from deforestation from 2000 to 2013 period [4]. Wibisono and Azham (2017) found that there are several medicinal plants in the conservation plot of the Kutai Kertanegara Regency forest that can be used as traditional medicine [5].

Graptophyllum pictum (L.) Griff is one of the medicinal plants that has not been conserved optimal yet. This plant has varieties of local names in Indonesia, such as daun wungu, handeuleum, and tulak. It has several properties according to the local ethnic. Most of the people in West Java used G. pictum to prevent postpartum infections, restore stamina, normalize the size of the uterus, stimulate breast milk production and reduce body weight [6]. G. pictum has antidiabetic activity by inhibiting the -glucosidase enzyme in vitro [7]. Extract of G. pictum in $70 \%$ ethanol can treat diabetes with a dose of 50 
$\mathrm{mg} / \mathrm{kg} /$ bodyweight based on the Intraperitoneal Glucose Tolerance Test (IPGTT) [8]. Andrianto et al. (2015) also found that $70 \%$ of G. pictum leaves ethanolic extract was able to protect pancreatic $\beta$-cells function in oxidative stress by alloxan injection in rats [9].

There are several reports about bioactivity studies of G. pictum, but the relationship of its genetic diversity with accession and ethnic aspects is currently unconfirmed. Thus, polymorphism studies and clusterization of G. pictum from 34 sample of 10 ethnics in Western Indonesia is important. We chose Sequence Related Amplified Polymorphism (SRAP) as molecular markers because it gives a good level of polymorphism in plant species. This study aimed to determine the polymorphism and kinship relations between ethnic groups and accessions of 34 samples G. pictum from 10 ethnics in Western Indonesia. This research will give a better understanding of supporting conservation, breeding strategies and the basis for developing G. pictum as an ethnopharmacological product in Indonesia.

\section{Experiments}

\subsection{Study Area}

The samples of this research were taken from South Sumatera, West Java, Central Java, East Java, West Kalimantan, North Kalimantan, South Kalimantan, and East Kalimantan Provinces in the Western part of Indonesia (GMT+7) (Table 1). South Sumatera samples were consisted of 4 accessions that were taken from Pegagan Ethnic, the ethnic lives in Ogan Ilir Regency which located about $35 \mathrm{~km}$ to the west from Palembang City. West Java samples were taken from Cirebon and Tasik Ethnics. Four accessions were taken from Cirebon Ethnic, the ethnic lives in Cirebon City which located $130 \mathrm{~km}$ to the northwest from Bandung City. Three accessions were taken from Tasik Ethnic, the ethnic lives in Tasikmalaya Regency which located $100 \mathrm{~km}$ to the southwest from Bandung City.

Table 1. Graptophyllum pictum (L.) Griff leaves from 10 ethnics in Western Indonesia.

\begin{tabular}{ccccc}
\hline Accession code & Ethnic & Province & East Longitude & Latitude \\
\hline $1-4$ & Pegagan & South Sumatera & $104^{\circ} 40^{\prime} 4^{\prime \prime}$ & $3^{\circ} 20^{\prime} 00^{\prime \prime} \mathrm{S}$ \\
$5,9,32,33$ & Cirebon & West Java & $108^{\circ} 33^{\prime} 00^{\prime \prime}$ & $6^{\circ} 20^{\prime} 00^{\prime \prime} \mathrm{S}$ \\
$7,10,34$ & Tasik & West Java & $108^{\circ} 13^{\prime} 30^{\prime \prime}$ & $7^{\circ} 19^{\prime} 56^{\prime \prime} \mathrm{S}$ \\
$8,19,20$ & Putak & North Kalimantan & $116^{\circ} 35^{\prime} 20.5^{\prime \prime}$ & $03^{\circ} 32^{\prime} 15.8^{\prime \prime} \mathrm{N}$ \\
$11-16$ & Kutai & East Kalimantan & $116^{\circ} 31^{\prime} 36^{\prime \prime}$ & $00^{\circ} 10^{\prime} 08^{\prime \prime} \mathrm{N}$ \\
$6,17,18$ & Ribun & West Kalimantan & $110^{\circ} 26^{\prime} 3.9^{\prime \prime}$ & $00^{\circ} 11^{\prime} 54.5^{\prime \prime} \mathrm{N}$ \\
$21-24$ & Sambas & West Kalimantan & $108^{\circ} 59^{\prime} 50.1^{\prime \prime}$ & $01^{\circ} 03^{\prime} 00^{\prime \prime} \mathrm{N}$ \\
$29-31$ & Pagatan & South Kalimantan & $115^{\circ} 20^{\prime} 00^{\prime \prime}$ & $03^{\circ} 15^{\prime} 00^{\prime \prime} \mathrm{S}$ \\
$25-27$ & Majapahit & East Java & $112^{\circ} 26^{\prime} 00^{\prime \prime}$ & $07^{\circ} 33^{\prime} 00^{\prime \prime} \mathrm{S}$ \\
28 & Jawa & Central Java & $110^{\circ} 50^{\prime} 00^{\prime \prime}$ & $07^{\circ} 35^{\prime} 00^{\prime \prime} \mathrm{S}$ \\
\hline
\end{tabular}

Central Java samples were taken from Java Ethnic that consists of 1 accession. The ethnic located in Surakarta Regency, $65 \mathrm{~km}$ northeast of Yogyakarta City. East Java samples consist of 3 accessions that taken from Majapahit Ethnic, located in Kediri Regency, $129 \mathrm{~km}$ to the west from Surabaya City. Samples of West Kalimantan was obtained from Ribun and Sambas Ethnics. Ribun Ethnic consist of 3 accessions which taken from Sanggau Regency, $186 \mathrm{~km}$ to the north of Pontianak City. Sambas Ethnic located in Bengkayang Regency, $227 \mathrm{~km}$ to the south of Pontianak City. We collected 4 accessions from Sambas Ethnic. North Kalimantan samples were taken from the Putak Ethnic that consists of 3 accessions, this ethnic located in Malinau Regency, in the west part of North Kalimantan Province. South Kalimantan samples consist of 3 accessions that were taken from the Pagatan Ethnic, this ethnic located in Tanah Bumbu Regency, $183 \mathrm{~km}$ to the north of Banjarmasin City. Samples of East Kalimantan were taken from Kutai Ethnic that consist of 7 accessions. This ethnic located in Kutai Kertanegara Regency. 


\subsection{Materials}

Equipment in this research were water baths (Memmert, Germany), electrophoretic device sets (Biorad, USA), Nano Pro spectrophotometer (Maestrogen, Taiwan), Gel Documentation System (Maestrogen, Taiwan), PCR (Biorad, USA), and refrigerated centrifuge (Tomy, Japan). The material used included 34 samples of Graptophyllum pictum (L) leaves from 10 ethnic groups in western Indonesia, liquid nitrogen, GeneJET Plant Genomic DNA Purification Mini Kit (Thermo Scientific, USA), Invitrogen proteinase-K (Thermo Fischer, USA), water, agarose (Thermo Fischer, USA), Safe DNA dye (Peq Lab, USA), Tris Borac-acid EDTA (TBE) (Sigma, Germany), DreamTaq Green PCR Master Mix (2X) (Thermo Scientific, USA), Invitrogen SRAP primer (Thermo Fischer, USA), Free Nuclease Water (Thermo Fischer, USA), Generuler ladder 100 and 1000 base pair (Thermo Fischer, USA). This study also used NTSYSpc (Numerical Taxonomy and Multivariate Analysis System) 2.1 and Pop Gene (Population Genetic Analysis) 1.3 software.

\subsection{Primary Selection and Annealing Temperature Optimization [10]}

The research began with the isolation of genomic DNA, including sample preparation, DNA extraction, electrophoresis and quantification of the isolate. Then the SRAP primer selection that matches the printed DNA and its temperature was optimized. There were 16 SRAP primer combinations tested (forward Me 1-4 and reverse Em 1-4 combination) as well as 8 annealing temperature combinations (between $33.0-58.0^{\circ} \mathrm{C}$ ). Subsequently, amplification of 34 DNA isolates using 8 selected primers through PCR was done, then the amplicon was visualized via electrophoresis (data not shown).

\subsection{Amplification of Genomic DNA Using SRAP Markers [10]}

DNA amplification was carried out twice during primary selection (16 primary combinations of 1 sample) and polymorphism test (8 primary combinations of 34 samples). Both used the PCR cocktail formula and the PCR cycle. The PCR reaction started with 1 initial denaturation cycle for $5 \mathrm{~min}$ at $94^{\circ} \mathrm{C}$. Then denaturation and annealing were $5 \mathrm{cy}$ cles with $1 \mathrm{~min}$ for each cycle. This denaturation used a temperature of $94{ }^{\circ} \mathrm{C}$. The first annealing used different temperatures according to the optimum temperature of the primer used. Next, 35 denaturation cycles $\left(94{ }^{\circ} \mathrm{C}\right)$, second annealing (temperature was according to the primer) and elongation $\left(72{ }^{\circ} \mathrm{C}\right)$, each for $1 \mathrm{~min}$. Furthermore, the final extension was finished once, at $72{ }^{\circ} \mathrm{C}$ for $8 \mathrm{~min}$. The reaction was complete when the sample was allowed to stand for approximately $10 \mathrm{~min}$ in PCR at $4{ }^{\circ} \mathrm{C}$ as holding temperature before visualization. The sample was visualized using Gel Documentation System.

\subsection{Data Analysis}

\subsubsection{Allele Scoring}

The base DNA fragments length from each accession from each primer was calculated. The presence of DNA fragments in each accession was given a different score number, the score is 1 if it shows there was a fragment and a score of 0 means there was no DNA fragment. Furthermore, monomorphic, polymorphic and total alleles of each primer were calculated to show that the primer meets the requirements to test the polymorphism of a species.

\subsubsection{Analysis of Diversity through Software NTSYS 2.1 and Pop Gene 1.3}

The Similarity Index was calculated using the DICE similarity index formula. We also obtained polymorphic percent for each population of G. pictum. The dendrogram construction was carried out using the Unweighted Pair Group Method Using Arithmetic Method (UPGMA). Then, Principal Component Analysis was performed to obtain Eigenvalue and cumulative variations of the main alleles in diversity. Subsequently, the ethnics were clustered based on the results of the NTSYS phylogenetic dendrograms. Data were 
interpreted and supported by gene migration data and allele frequencies. Furthermore, the data were visualized as a map of the distribution and classification of G. pictum from western Indonesia.

\section{Results}

\subsection{Polymorphic-Monomorphic Determination}

The eight selected primer combinations were applied to 34 isolated DNA genomes of G. pictum. Electrophoresis result of 34 PCR samples at 2.5\% agarose showed the presence of polymorphism and monomorphism bands. The monomorphism in this research was demonstrated by the presence of identical or similar allele patterns in 28 samples. It means that the appearance of the ribbon in 28 samples categorized monomorphic. The polymorphic was shown by the variety of the patterns of band appearance with the same size in the sample being tested. The results were scanned into binary data and processed using NTSYS software (data not shown). Subsequently, there were 45 selected fragments (alelles) as variables and 34 individuals representing 10 different ethnicities (Table 2).

Table 2. Total of DNA fragment from amplification of each locus in 8 primer combinations.

\begin{tabular}{cccccc}
\hline $\begin{array}{c}\text { Annealing I and II } \\
\text { Temperimer Com- } \\
\text { bination }\end{array}$ & $\begin{array}{c}\text { Total Al- } \\
\text { lele }\end{array}$ & $\begin{array}{c}\text { Monomor- } \\
\text { phic Allele }\end{array}$ & $\begin{array}{c}\text { Polymorphic } \\
\text { Percent (\%) }\end{array}$ & $\begin{array}{c}\text { Fragment } \\
\text { Sizes (bp) }\end{array}$ \\
\hline $35.2-47.5$ & Me 1-Em 4 & 3 & 2 & 33.34 & $200-800$ \\
$44.0-57.0$ & Me 2-Em 2 & 4 & 0 & 100.00 & $90-300$ \\
$44.0-57.0$ & Me 2-Em 3 & 12 & 3 & 75.00 & $90-1200$ \\
$35.2-47.5$ & Me 2-Em 4 & 5 & 2 & 60.00 & $90-1000$ \\
$44.0-57.0$ & Me 3-Em 1 & 7 & 4 & 42.86 & $90-1000$ \\
$44.0-57.0$ & Me 3-Em 3 & 8 & 0 & 100.00 & $90-1500$ \\
$44.0-57.0$ & Me 3-Em 4 & 3 & 0 & 100.00 & $90-250$ \\
$35.2-47.5$ & Me 4-Em 3 & 3 & 1 & 66.67 & $90-200$ \\
\hline Total & & 45 & 4 & 577.87 & - \\
\hline Average & & 5.63 & 0.50 & 72.23 & - \\
\hline
\end{tabular}

In addition to the diversity shown by allele frequencies, PopGene can also indicate the value of gene flow or migration. Two loci specifically give rise to a migration value of 0 and Genetic diversity (Gst) of 1, namely the alleles 24th and 41st. So that these two alleles have the potential to become specific marker alleles for G. pictum from the Ribun ethnic origin.

\subsection{Diversity of Intra-Population based on Ethnicity}

We can see the genetic diversity in a population according to ethnicity (Table 3). The Shannon Index (I) in each ethnic corresponds to a low level of diversity due to I1. Populations of G. pictum with high percent polymorphic loci were Kutai $(55.56 \%)$, Pegagan $(48.89 \%)$ and Sambas $(48.89 \%)$, respectively. While ethnicities with the lowest polymorphism were Pagatan $(8.89 \%)$, Tasik (15.56\%) and Putak (15.56\%), respectively. The number of observed alleles $(\mathrm{Na})$ is relatively low due to the limited sample size of each ethnic group. The value of effective allele $(\mathrm{Ne})$ is proportional to the number of heterozygous individuals in the population. 
Table 3. Genetic variety of each population based on ethnic.

\begin{tabular}{cccccccc}
\hline Population & Total Samples & $\mathbf{N a}^{\mathbf{1}}$ & $\mathbf{N e}^{2}$ & $\mathbf{H}^{3}$ & $\mathbf{I}^{4}$ & Polymorphism Locus & $\begin{array}{c}\text { Polymorphic } \\
\text { Percent (\%) }\end{array}$ \\
\hline Cirebon & 4 & 1.4000 & 1.2756 & 0.1611 & 0.2366 & 18 & 40.00 \\
Tasik & 3 & 1.1556 & 1.1244 & 0.0691 & 0.0990 & 7 & 15.56 \\
Majapahit & 3 & 1.2889 & 1.2311 & 0.1284 & 0.1839 & 13 & 28.89 \\
Jawa & 1 & 1.0000 & 1.0000 & 0.0000 & 0.0000 & 0 & 0.00 \\
Sambas & 4 & 1.4889 & 1.3111 & 0.1889 & 0.2807 & 22 & 48.89 \\
Ribun & 3 & 1.4222 & 1.3378 & 0.1877 & 0.2688 & 19 & 42.22 \\
Pagatan & 3 & 1.0889 & 1.0711 & 0.0395 & 0.0566 & 4 & 8.89 \\
Kutai & 6 & 1.5556 & 1.4297 & 0.2383 & 0.3434 & 25 & 55.56 \\
Putak & 3 & 1.1556 & 1.1244 & 0.0691 & 0.0990 & 7 & 15.56 \\
Pegagan & 4 & 1.4889 & 1.4089 & 0.2194 & 0.3127 & 22 & 48.89 \\
\hline Average & 3.40 & 13.04 & 12.31 & 0.1302 & 0.1881 & 13.70 & 30.45 \\
\hline
\end{tabular}

${ }^{1} \mathrm{Na}=$ total observed allele, ${ }^{2} \mathrm{Ne}=$ total effective allele, ${ }^{3} \mathrm{I}=$ Shannon index,${ }^{4} \mathrm{H}=$ heterozygosity.

\subsection{Diversity and Phylogenetic between Accessions}

Phylogenetic trees can be obtained from 28 G. pictum accessions of 10 ethnics in Western Indonesian through the Numerical Taxonomy System (NTSYS) software (Figure 7). The Dissimilarity Index (DI) between 34 accessions can reach a maximum value of 0.6444 obtained from the accession 6 and 30 (Ribun and Pagatan). The second highest DI value was 0.6222 represents the genetic distance between the accession 6 and 31 (Ribun and Pagatan). The maximum DI value in this research was classified as moderate, but higher than the DI between ethnicity with a maximum DI value of 0.4359 (Figure 1). Individual diversity ranges from $5-80 \%$ based on the dendrogram.

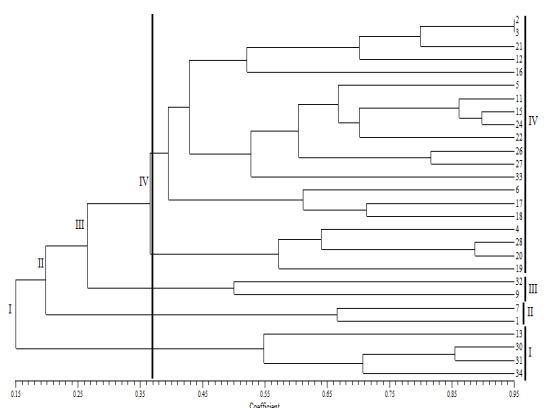

Figure 1. Phylogenetic tree of 34 accession G. pictum from 10 ethnics in Western Indonesia using UPGMA method. Clusterization coefficient $=0.37$ (Dissimilarity Index 0.63).

\section{Discussion}

The numbers at the end of the phylogenetic tree showed accession clusterization of G. pictum in Western Indonesia (Figure 1). We obtained four clusters based on the coefficient value of 0.37 or a diversity index of 0.63 . Accession that has the closest diversity based on DI was the accession of 28 and 20 (Jawa-Putak) also 30 and 31 (Pagatan-Pagatan) with DI of 0.02222. After that, the close diversity was accessions of 2 and 3 (Pegagan-Pegagan) also 15 and 24 (Kutai-Sambas) with DI of 0.04444. Clusterization was expected to be able to inform genetic similarity patterns, making it easy to make cross maps for the development of superior varieties of G. pictum.

Figure 2 shows the clusterization of G. pictum in Western Indonesia was random, it did not follow the pattern of geographical proximity. Cluster I consist of all accessions from Pagatan Ethnic and several accessions from Tasik and Kutai Ethnics. Cluster II consists of several accessions from Tasik and Pegagan Ethnics. Cluster III consists of several 
accessions from Cirebon Ethnic. Cluster IV consists of all accessions from all ethnic, except Pagatan and Tasik Ethnics. The pattern of the genetic closeness of G. pictum populations is thought to be the role of humans in mixing genes between populations such as the $A n$ thocephalus cadamba tree in Indonesia [11]. Many studies report that humans play a large role in shaping the genetic structure of a population, domestication and mixing origins [12]. Thus, ethnic migration is one of the important factors that determine the kinship of G. pictum.

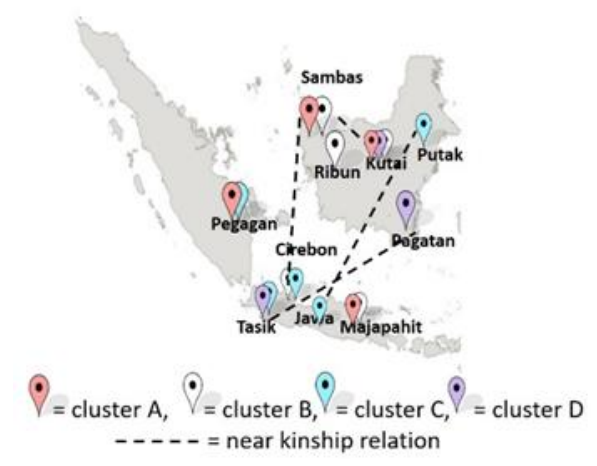

Figure 2. Clusterization map of Graptophyllum pictum in Western Indonesia.

\section{Conclusions}

The mean polymorphic percent of 16 primary SRAP combinations was $72.23 \%$. G. pictum with the closest genetic distance comes from the ethnic Tasik (West Java) and Pagatan (South Kalimantan) (ID = 0.0094). The accession with the furthest genetic distance is the accession 6 and 30 (ID = 0.6444) of the Ribun (West Kalimantan) and Pagatan ethnic groups. G. pictum of Ribun ethnic origin is the oldest ancestry. High polymorphism G. pictum population comes from Kutai (East Kalimantan) (polymorphic percent $=55.56 \%$ ). In general, G. pictum polymorphisms in Western Indonesia are classified as moderate (ID $<0.69)$. G. pictum clusterization from Western Indonesia does not show a pattern that suits its ethnicity or geography.

Author Contributions: D.A. and P.J.P. are the recipients of the research grant and designed the experiments; U.M.S. and D.O.P. performed the experiments; S.H. analyzed the data; D.S. and A.M. contributed samples; D.A. wrote the paper.

\section{Institutional Review Board Statement:}

Informed Consent Statement:

Data Availability Statement:

Acknowledgments: The authors would like to acknowledge to Medicinal Plant and Traditional Medicine Research and Development Centre, National Institute of Health and Research Development, Ministry of Health that has funded this research through RISTOJA 2018 program.

Conflicts of Interest: The authors declare no conflict of interest.

\section{References}

1. Margono, B.; Potapov, P.; Turubanova, S.; Stolle, F.; Hansen, M.C. Primary forest cover loss in Indonesia over 2000-2012. Nat. Clim. Chang. 2014, 4, 730-735, doi:10.1038/nclimate2277.

2. Naidu, M.T.; Kumar, O.A. Tree diversity, stand structure and community composition of tropical forests in Eastern Ghats of Andhra Pradesh, India. J. Asia Pasific Divers. 2016, 9, 328-334, doi:10.1016/j.japb.2016.03.019. Available online: https://www.sciencedirect.com/science/article/pii/S2287884×16300280 (accessed on 28 February 2021).

3. Lillo, E.P.; Fernando, E.S.; Lillo, M.J.R. Plant diversity and structure of forest habitat types on Dinagat Island, Philippines. J. Asia Pasific Divers. 2018, 12, 83-105, doi:10.1016/j.japb.2018.07.003. Available online: https://www.sciencedirect.com/science/article/pii/S2287884×17301668 (accessed on 28 February 2021). 
4. Ahmad, A.; Saleh, M.B.; Rusolono, T. Spatial model of deforestation in FMU of Poigar, North Sulawesi. J. Penelit. Kehutan. Wallacea 2016, 5, 159-169, doi:10.18330/jwallacea.2016.vol5iss2pp159-169. Available online: https://jurnal.balithutmakassar.org/index.php/wallacea/article/view/114 (accessed on 28 February 2021).

5. Wibisono, Y.; Azham, Z. Inventory of medicinal potentially plant on medicinal plants conservation plot in KHDTK Samboja, Samboja sub district of Kutai Kartanegara Regency. Indones. J. Agric. For. 2017, 16, 125-140.

6. Rosmala, A.; Khumaida, N.; Sukma, D. Morphological changes and growth of handeuleum (Graptophyllum pictum L. Griff) due to gamma ray irradiation. J. Agron. Indones. 2015, 43, 235-241, doi:10.24831/jai.v43i3.11250. Available online: https://journal.ipb.ac.id/index.php/jurnalagronomi/article/view/11250 (accessed on 28 Februari 2021).

7. Nurcholis, W.; Andrianto, D.; Falah, S.; Katayama, T. $\alpha$-Glucosidase Inhibitor and Cytotoxic Activities and Phytochemical Screening of Graptophyllum pictum (L.) Griff. In Proceeding of the 3rd International Symposium of Indonesian Wood Research Society (IWoRS), Yogyakarta, Indonesia, 3-4 November 2011; pp. 87-93.

8. Andrianto, D.; Nurcholis, W.; Katayama, T.; Suzuki, T. Antidiabetic and antioxidant anctivity of $70 \%$ ethanolic extract of Graptophyllum pictum improves glucose resistance in rats. J. For. Biomass Util. Soc. 2014, 9, 31-36.

9. Andrianto, D.; Nurcholis, W.; Katayama, T.; Suzuki, T. 70\% ethanolic extract of Graptophyllum pictum leaves protects pancreas $\beta$-cell in rats by antioxidant mechanism. J. For. Biomass Util. Soc. 2015, 10, 49-54.

10. Li, G.; Quiros, C.F. Sequence-Related Amplified Polymorphism (SRAP), a new marker system based on a simple PCR reaction: Lts application to mapping and gene tagging in Bressica. Theor. Appl. Genelics 2001, 103, 455-461, doi:10.1007/s001220100570. Available online: https://link.springer.com/article/10.1007/s001220100570 (accessed on 28 February 2021).

11. Nurtjahjaningsih, I.L.G.; Qiptiyah, M.; Pamungkas, T.; Widyamoko, A.Y.P.B.C.; Rimbawanto, A. Genetic diversity characterization of Anthocepalus cadamba population revealed by Random Amplified Polymorphism DNA. J. Pemuliaan Tanam. Hutan 2014, 8, 81-92. Accessible online: https://www.forda-mof.org/files/Jurnal_Pemuliaan_8.2.2014-4.ILG_Nurjahaningsih,_dkk.pdf (accessed on 28 February 2021).

12. Mccusker, M.R.; Mandrak, N.; Egeh, B.; Lovejoy, N.R. Population Structure and Conservation Genetic Assessment of the Endangered Pugnose Shiner, Notropis Anogenus. Conserv. Genet. 2014, 15, 343-353, doi:10.1007/s10592-013-0542-3. Available online: https://europepmc.org/article/agr/ind500739515 (accessed on 28 February 2021). 